Colloquia Litteraria

UKSW

$2 / 2015$

WOJCIECH KUDYBA

\title{
MIEJSCE I PAMIĘĆ W PÓŹNEJ TWÓRCZOŚCI MARKA NOWAKOWSKIEGO. PROLEGOMENA
}

Jeśli rzeczywiście recepcja twórczości Marka Nowakowskiego utknęła w ostatnich latach w samym środku łachy zużytych uogólnień i mniej lub bardziej mylących stereotypów, to warto zauważyć, że nadzieję na odświeżenie i pogłębienie spojrzenia na utwory tego wciąż niedocenionego pisarza przynosi narastająca fala zainteresowania przestrzenią literacką, zwana niekiedy przełomem topograficznym w nauce o literaturze ${ }^{1}$. Pośród kategorii otwierających ciekawe perspektywy badawcze warto wskazać m.in. tzw. „miejsca pamięci”. Choć stały się one ostatnio niebywale poręcznym narzędziem badawczym i tchnęły nowe życie w badania nad motywami przestrzennymi, wśród materiału literackiego, który poddany został zmasowanej eksploracji, wciąż brakuje utworów Nowakowskiego. Sytuacja wydaje się osobliwa głównie dlatego, że niepodobna zaprzeczyć, iż od lat 90. XX wieku ten akurat pisarz systematycznie poszerza budowany przez siebie krąg prozy wspomnieniowej ${ }^{2}$ (a nawet szeroko

1 Obszernie pisze o tym w swych pracach Elżbieta Rybicka, por. np. Elżbieta Rybicka, Od poetyki przestrzeni do polityki miejsca. Zwrot topograficzny w badaniach literackich, „Teksty Drugie” 2008, nr 4, a zwłaszcza tejże, Geopoetyka. Przestrzeń i miejsce we wspótczesnych teoriach i praktykach literackich, Kraków 2014.

2 Myślę o takich utworach jak: Powidoki. Chłopcy z tamtych lat, Warszawa 1995; Powidoki 2. Wspomnij ten domek na Gęsiówce..., Warszawa 1996; Powidoki 3. Warszawiak pilnie poszukiwany!, Warszawa 1998; Nekropolis, Warszawa 2005; Nekropolis 2, Warszawa 2008 (w dalszych częściach artykułu opatruję je skrótami, odpowiednio: $\mathrm{P}_{1}, \mathrm{P}_{2}, \mathrm{P}_{3}, \mathrm{~N}_{1}, \mathrm{~N}_{2}$ ), oraz Mój słownik PRL-u, Warszawa 2002. 
rozumianej intymistyki ${ }^{3}$ ), w której impulsem wywołującym obrazy z przeszłości są przede wszystkim elementy przestrzeni.

\section{Antropologia knajpy}

Przenosząc do badań nad literaturą kategorię miejsca pamięci, trudno ominąć często ostatnio eksploatowany fragment artykułu Andrzeja Szpocińskiego, omawiający sposób rozumienia tego pojęcia, proponowany wiele lat temu przez Pierre'a Norę:

Terminu tego nigdzie dokładnie nie zdefiniował, ale jak się wydaje rozumiał go wtedy przede wszystkim jako zinstytucjonalizowane formy zbiorowych wspomnień przeszłości. „Miejscem pamięci” mogło być dla niego zarówno archiwum historyczne czy pomnik bohatera, jak i mieszkanie prywatne, w którym spotykają się zazwyczaj kombatanci, by obchodzić uroczystości z powodu jakiejś ważnej dla nich rocznicy ${ }^{4}$.

Jak czytamy nieco dalej, francuski historyk ma na myśli nie tylko miejsca upamiętniające ważne wydarzenia historyczne, lecz także, a nawet przede wszystkim „miejsca, w których się wspomina”. Chodzi przy tym - warto to podkreślić - o pamięć zbiorową, regulowaną kulturowo, a czasem też instytucjonalnie ${ }^{5}$. Literaturoznawcy zwracają uwagę, że tak rozumianej kategorii nie da się bezkrytycznie przenieść do refleksji mającej nieco inny przedmiot niż - rozmaicie ewokowane - pamięć społeczna lub świadomość historyczna. Wszak przestrzeń w prozie i poezji jest wytworem działań artystycznych, jej związek z przestrzenią realną jest możliwy, ale niekonieczny. Literackie miejsca pamięci mają specyficzny status bytowy - są wyobrażeniami stworzonymi $z$ toponimów, nazw innego rodzaju, mniej lub

\footnotetext{
3 Por. Pióro. Autobiografia literacka, Warszawa 2012; Dziennik podróży w przeszłość, Warszawa 2014; Okopy Świętej Trójcy. Rozmowy o życiu i ludziach. Z Markiem Nowakowskim rozmawia Krzysztof Świątek, Poznań 2014.

4 Andrzej Szpociński, Miejsca pamięci (Lieux de memoire), „Teksty Drugie” 20o8, nr 4, s. 11-12.

5 Tamże, s. 13-14.
} 
bardziej sugestywnych opisów itp. ${ }^{6}$. Obiektem obserwacji może więc stać się sam proces deskrypcji - który jest wysiłkiem przekształcania realnego locum w miejsce literackie - trud budowania mitu tego lub innego miejsca.

Równie często podkreśla się także fakt, że literackie miejsca pamięci - inaczej niż te realne - mają charakter indywidualny, są związane z jednostką i jej pamięcią biograficzną. Jak pisze Maria Delaperrière:

W literaturze [...] sytuacja jest dużo bardziej złożona, ponieważ $\mathrm{z}$ jednej strony pamięć indywidualna podlega regulacji kulturowej i wpisuje się we wspólny kod społeczno-kulturowy - z drugiej strony dąży do twórczej niezależności, tworzy fikcję literacką, która także ten kod może wzbogacać!?.

Wydaje się, że w późnej prozie Marka Nowakowskiego funkcjonuje co najmniej jeden typ zmityzowanej przestrzeni, „w której się wspomina”. Pisarz pokazuje pewne realne loci, które można potraktować jako „własność” pewnych grup społecznych, co oznacza, że stały się one metaforycznym centrum tożsamości zbiorowej, głównie lokalnej. Zarazem jednak na swój sposób je mitologizuje, daje do zrozumienia, że są one ważne jako swoisty „skarbiec” wartości ważnych dla specyficznych, wewnętrznie zróżnicowanych grup społecznych. Co więcej: że odwiedzanie, czy nawet obrzędowe „nawiedzanie” tych pomieszczeń było sposobem uczestnictwa w owych istotnych wartościach choćby w taki sposób, że wiązało się z rytuałami przypominania wzorów zachowań, idei i norm uznawanych za słuszne.

Wciąż czeka na swego monografistę swoista antropologia knajpy w twórczości Nowakowskiego. Pisarz nie tylko przecież - jak chce Artur Nowaczewski - „tworzy katalog pijalni, mordowni i dokonuje

\footnotetext{
6 Por. Małgorzata Czermińska, Miejsca autobiograficzne. Propozycja $w$ ramach geopoetyki, „Teksty Drugie” 2011, nr 5, s. 187.

7 Maria Delaperrière, Miejsca pamięci czy pamięć miejsc? Kilka refleksji na temat uobecniania przeszłości w literaturze współczesnej, „Ruch Literacki” 2013, z. 1, s. 51.
} 
ich rodzajowej systematyzacji", ale także, a nawet przede wszystkim podejmuje się ich reinterpretacji. Nie tylko więc - co zdaje się sugerować badacz - uzupełnia wiedzę „pomieszczoną w Złym”" Leopolda Tyrmanda, ale również konsekwentnie pogłębia semiotykę rozmaitych lokali gastronomicznych jako miejsc spotkań o charakterze zarówno biesiadnym, jak i nieomal duchowym. Tworzą one zresztą układ wyraźnie zhierarchizowany. Są to restauracje, kawiarnie, bary, knajpy i spelunki, ich obrazu nie da się zatem sprowadzić do opisu wyłącznie tych ostatnich.

W drugim tomie Powidoków odnajdujemy między innymi następującą opinię:

Niezapomniana knajpa na Wiejskiej kojarzy się przede wszystkim $\mathrm{z}$ wyobraźnią, sztuką, wyżynami ludzkiego ducha [P2, s. 125].

Starając się udowodnić tak postawioną tezę, pisarz próbuje zburzyć stereotypowy obraz zbiorowości, jaką tworzyli bywalcy podobnych lokali. Z niemałą satysfakcją pisze na przykład:

W kawiarni Metropolu [...] spotykałem Zygmunta Kubiaka [...]. Siedział przy stoliku, pogrążony w lekturze maszynopisów, słowników, pośród ciżby waluciarzy, studentów, dziewczyn lekkich obyczajów, kombinatorów i innych osób podejrzanego autoramentu [...] [N1, s. 121].

Okazuje się, że kawiarnia - a także knajpa, bar, tym bardziej zaś melina - są dla Nowakowskiego heterotopiami ${ }^{10}$, kontrmiejscami, przestrzeniami kontestacji każdego locum określonego przez ideologię i usankcjonowanego w ramach kontrolowanych przez nią

\footnotetext{
${ }^{8}$ Artur Nowaczewski, Szlifibruki i flâneurzy. Figura ulicy w literaturze polskiej po 1918 roku, Gdańsk 2011, s. 106.

9 Tamże, s. 107.

10 Pojęcia heterotopii używam tu w takim znaczeniu, jakie nadał mu w swym głośnym wykładzie Michel Foucault, por. tegoż, Inne miejsca, tłum. Agnieszka Rejniak-Majewska, „Teksty Drugie” 2005, nr 6, s. 117-125.
} 
obyczajów społecznych ${ }^{11}$. Pisarz daje do zrozumienia, że niepozorna nawet restauracja stawała się bastionem wolności - także dla przedstawicieli władzy, a nawet służb bezpieczeństwa, nawiedzających podobne przybytki w chwilach znużenia sprawowanymi rolami. Stając się przestrzenią spontanicznych, często mimowolnych zwierzeń i wspomnień, w oczywisty sposób uchylała się przed kontrolą, była miejscem poza zasięgiem propagandy ${ }^{12}$, a więc i poza mechanizmami sterowania społeczną pamięcią.

Spośród rozmaitych bywalców peerelowskich lokali gastronomicznych Nowakowski w szczególny sposób wyróżnia właśnie tych, którzy byli depozytariuszami zakazanych, tabuizowanych form pamięci zbiorowej. W jednym ze swych wspomnień kreśli syntetyczny, zbiorowy portret tej grupy osób:

Byli to ludzie, dla których żywa pozostała Warszawa lat przedwojennych [...]. Stare domy, ulice, knajpy, kabarety. Dawne historie, ludzie. Wszystko żyło w ich pamięci. Cóż to były za persony! [P1, s. 47].

Niejeden raz natrafiamy w późnej twórczości Nowakowskiego na rozmaite indywidualne portrety „łączników czasu przeszłego z teraźniejszym” (P2, s. 82). Dowiadujemy się, że są ważni, bo bez nich „nie ma w ogóle przeszłości” (tamże). O jednym z nich przeczytamy:

Uderzała jego znajomość zakazanych rewirów Warszawy, bazarów, dworców, melin i barwnych postaci stamtąd. Był chłopakiem z miasta [P2, s. 88].

Przestrzeniom oficjalnym pisarz zdaje się przeciwstawiać miejskie peryferie; narracjom socjalistycznej władzy - opowieści lokalne; tożsamości państwowej - zakorzenienie we wspólnocie lokalnej, „w mieście”; ideologicznej utopii - autentyczność życia. Dworcowy

\footnotetext{
$11 \mathrm{Ku}$ podobnym wnioskom prowadzi m.in. recenzja Nekropolis pióra Adama Poprawy. Por tegoż, Knajpy niepodległościowe, „Twórczość” 20o6, nr 5, s. 120-122. ${ }_{12}$ Zwraca na to uwagę m.in. Jerzy Madejski w tekście "Upiliśmy się serdecznie», „Nowe Książki” 20o6, nr 4, s. 35-36.
} 
bar, jak czytamy, „nie tylko był przytuliskiem wykolejeńców, dziwek i pijaków. Równie silnie przyciągał badaczy życia” (P2, s. 75).

„Koneserzy egzystencji” to postaci pełniące w świecie wspomnień Nowakowskiego specjalną funkcję. Knajpa - warto to podkreślić jest przestrzenią kultury oralnej. Pamięć jest w niej przekazywana wyłącznie za pomocą narracji mówionej. W tego typu kulturach swoiste prawo do opowieści zyskują wyłącznie ci, którzy uzyskali status mędrca. Mędrcem zaś może stać się tyko ten, kto poznał rozległe, zróżnicowane pasmo życia. Właśnie dlatego Nowakowski pisze:

Moją fascynację Adamem [Pawlikowskim] wzmagała jego wiedza o życiu; zachowywał się równie swobodnie wśród węglarzy i opryszków w knajpie u Klimka na Próżnej, jak wśród koryfeuszy sztuki w klubie SPATIF-u w Alejach Ujazdowskich [N 1, s. 122].

Wśród mistrzów pamięci wymienia też Adama Mauersbergera, „który był poetą opowieści o mieście i ludziach" (P1, s. 39, por. także $\mathrm{N}$ 1, s. 18).

Knajpa to zatem dla pisarza przede wszystkim miejsce, w którym lokalna wspólnota, tkwiąca głęboko korzeniami w swoim mieście, spotyka się, by świętować niezwykły spektakl ewokacji jego przeszłości. W pierwszym tomie Powidoków przykuwa uwagę znamienna, przywołana z pamięci scena:

Znajdujemy się przecież w zadymionej salce w Samsonie przy bufecie Andrzej Babicz opowiada niezmordowanie [P1, s. 6o].

Jedna $\mathrm{z}$ warszawskich restauracji (istniejąca do dziś) została tu przedstawiona właśnie jako miejsce swoistej „dekolonizacji” pamięci - uwolnienia jej z uścisku narracji władzy na rzecz dyskursów małych społeczności. Znamienna wydaje się użyta przez narratora liczba mnoga - wskazująca na pewne audytorium opowiadającego, na wspólnotę zgromadzoną wokół jego słów. Mamy do czynienia z opisem swoistego rytuału, którego częścią są nie tylko długie monologi jednego z „kapłanów pamięci”, ale też zapachy i kolory, tworzące niepowtarzalny nastrój. 


\section{Flâneur}

W późnej prozie Nowakowskiego dominującą rolę grają jednak inne formy celebracji pamięci. Ich najważniejszym bohaterem i narratorem jest przecież flâneur ${ }^{13}$. Choć Artur Nowaczewski wspomina w cytowanym opracowaniu (zob. przyp. 8) o jego wędrówkach ulicami i dzielnicami współczesnej Warszawy, to jednak niewiele miejsca poświęca interpretacji kategorii pamięci, stąd też poniższe uzupełnienia. Warto przede wszystkim zwrócić uwagę na podkreślaną przez pisarza symbiozę ruchu w przestrzeni i w czasie. Wędrówka ulicami miasta jest dla bohatera i narratora omawianej autobiograficznej prozy zarazem wyprawą w głąb tego, co minione. Opowieść wpisuje się w figurę drogi, przemieszczanie się w przestrzeni staje się rytuałem przywoływania wspomnień. W jednym $z$ tomów natrafiamy na wyznanie, które ma charakter wyraźnej autoprezentacji:

Piszący te słowa, który we wczesnych latach pięćdziesiątych snuł się niezmordowanie ulicami miasta, pamięta doskonale Waldka Szramkę [P2, s. 42].

Przywołana w cytowanej wypowiedzi perspektywa czasowa wskazuje, że mamy do czynienia z kimś, kto z niespiesznych spacerów ulicami miasta uczynił swoisty sposób życia - z wędrowcem permanentnym. W jednym ze swych tekstów felietonista próbuje nadać perypatetyckim wyprawom rangę niemal metafizyczną, pisząc:

Jeżeli wyobrazić sobie życie w mieście jako wędrówkę, to początek następuje przeważnie w szpitalu położniczym, a potem trwa wieloletnie przemierzanie ulic, nieustanna wędrówka w zamkniętym obszarze [...] [P1, s. 232].

W rzeczywistości stroni jednak od figury homo viator, nadając swej wędrówce charakter wyłącznie horyzontalny, zamknięty w perspektywie doczesności, podporządkowany funkcjom poznawczym i memoratywnym. Mocno podkreśla natomiast wspólnototwórczy

\footnotetext{
13 Pisze o tym m.in. Ewa Nawój w recenzji Nekropolis 2 zatytułowanej Perypatetyk warszawski, „Nowe Książki” 2008, nr 4, s. 62-63.
} 
wymiar spacerów. Ten, kto czyni z nich swoją pasję, rychło spotyka tych, którzy także się jej oddają. W jednym ze szkiców odnajdujemy znamienne wyznanie:

Zacząłem go spotykać w latach pięćdziesiątych, sam będąc już nałogowym wędrowcem odkryłem, że ma on podobne upodobania do moich [P2, s. 182].

W innym miejscu dowiadujemy się, że do grona warszawskich wędrowców należeli również między innymi Tadeusz Peiper, Miron Białoszewski czy też Julian Stryjkowski, który - jak podkreśla pisarz - „piechurem był zawołanym. Mógł chodzić godzinami” $\left(\mathrm{N}_{1}\right.$, s. 41). Kiedy indziej przypomina Nowakowski szlak wędrówek grupy młodych literatów warszawskich w latach pięćdziesiątych:

Miejsce znajdowało się na tak zwanym szlaku i od razu można było przenieść się naprzeciw [...] Szlak pielgrzymów wiódł dalej do sklepu z piwem [...] winiarni u Hopfera, kawiarni Literatów, aż do Manekina, klubu w piwnicy na Starym Mieście, który wieńczył nocną wędrówkę [N1, s. 97].

Pierwszy z cytowanych wyżej fragmentów zwraca jednak uwagę przede wszystkim na fakt, że wędrówka nie tylko pomaga wrosnąć w tkankę miasta - w jego architekturę, pejzaż i ludzi - ale także, dzięki pracy pamięci, przechować ją w sobie, ocalić przed niszczącym strumieniem czasu, uchronić przed zapomnieniem. Pamięć flâneura ma charakter autobiograficzny - to oczywiste. Wydobywa z przeszłości to, czego doświadczył on osobiście, czego był świadkiem, lub to, o czym od bezpośrednich świadków usłyszał. Warszawa, o której mówi, to jego „prywatne”, przez wiele lat oswajane miasto ${ }^{14}$. To przestrzeń złożona z jego osobistych przywiązań do miejsc - tych, a nie innych, bo to właśnie te, a nie inne odegrały w jego życiu jakąś szczególną rolę. Właśnie dlatego w omawianym korpusie tekstów bardzo rzadko natrafiamy na stwierdzenia typu: „Może to było z 1952 na 1953 rok? Nie

14 O pełnionej przez Nowakowskiego roli prywatnego historyka Warszawy pisze Adam Tyszka w eseju Kronikarz miasta, „Twórczość” 2008, nr 8, s. 108-110. 
pamiętam" (P2, s. 18). O wiele częściej odnajdujemy sytuacje, które można nazwać epifaniami przeszłości. Ich istotą jest doświadczenie nagłej naoczności, niemal dotykalności tego, co minione. Narrator zwierza się na przykład: „Ilekroć tu przychodzę, zawsze widzę Toruńską" (N1, s. 7). Kiedy indziej kreśli następujący obraz:

Przystaniesz i nagle ciemność blednie, rozjaśnia się. Wyłaniają się jakieś obrazy, jacyś ludzie. Zrazu zamazane kontury, mgliste. Nabierają wyrazistości. Wszystko zmartwychwstaje z niczego. Oto ulica Wspólna [N1, s. 7].

Metaforyka rezurekcyjna sytuuje proces wspominania w kręgu sakralnego rytuału. Scena zdaje się przypominać obrzęd dawnych dziadów. Narrator wciela się w rolę guślarza, który w trakcie ceremonii staje się „widzącym” - widzi postaci i obrazy wywołane z przeszłości ${ }^{15}$. Scena jest ważna, bo cytowany fragment pełni w Nekropolis specjalną funkcję. Wpisany w topikę początku zapowiada charakter i treść całej książki. Ma być ona właśnie ewokacją tego, co minęło. Miasto-nekropolia to miasto-ślad, miejsce pełne znaków odsyłających w głąb czasu. Narrator Nekropolis jest tym, który potrafi je odczytać, tym, który widzi, bo pozwala się minionemu ogarnąć i przeniknąć:

To dawne, nie istniejące ogarnęło znienacka. Bazar zajmował rozległy obszar wzdłuż Polnej do Nowogrodzkiej naprzeciw gmachu Politechniki. To był matecznik [P1, s. 155].

To właśnie dzięki swej autobiograficznej pamięci bohater późnej prozy Nowakowskiego jest w stanie dostrzec palimpsestową strukturę miasta i uruchomić proces odsłaniający, skrytą pod jego obecnymi architektonicznymi warstwami obecność dawnych ulic, placów, monumentów czy też - jak w tym przypadku - bazarów. Pamięć sprawia również, że punktem odniesienia dla współczesnej Warszawy już na zawsze pozostanie dla niego ta, która była towarzyszką jego młodości.

15 Podobny trop podpowiada Mieczysław Orski w szkicu Proszq nas o Zdrowaś Maria, „Przegląd Powszechny” 2008, nr 6, s. 127-129. 
Zdarza się, że epifanie przeszłości podszyte są w omawianej prozie nostalgią ${ }^{16}$.

Podlega ona zresztą u Nowakowskiego wyraźnej tematyzacji, staje się cechą ponadindywidualną, znamieniem wspólnoty wspomnianych warszawskich „znawców życia” i wędrowców. Wyznania typu: „Kiedyś to była ulica [...] kiedyś to było miasto” (P2, s. 69) padają tu z ust różnych osób i w różnych sytuacjach. Czemu służą? Czy trzeba w nich widzieć jedynie płaską realizację toposu ubi sunt, ujawniającą żal za bezpowrotnie minioną młodością? A może są po prostu objawem nieumiejętności odnalezienia się w zmieniającej się rzeczywistości, świadectwem zagubienia? Choć z ust recenzentów ostatnich książek pisarza padały niekiedy podobne sugestie ${ }^{17}$, wydaje się, że flâneur Nowakowskiego pozostaje mimo wszystko bystrym i trzeźwym obserwatorem nowoczesności i ma ważne, niekiedy wyraźnie artykułowane powody, by pozytywnie waloryzować miasto przeszłości. Od współczesnych apologetów miejskiej tkanki Warszawy różni się tym, że dysponuje stałym układem odniesienia, jaki stanowi pamięć jej dawnej postaci. Jego oceny nigdy nie są zupełnie dowolne i arbitralne. Ich źródłem są nie tylko emocje, lecz także, a nawet przede wszystkim zdrowy rozsądek, który nakazuje porównać teraźniejsze z minionym, by zważyć zalety i wady jednego i drugiego. Czytelnik późnej prozy pisarza często może także odnieść wrażenie, że zwrot pisarza w stronę przeszłości ma charakter etyczny, jest motywowany prostym odruchem moralnym, gotowością „bycia po stronie słabszych”. Przedmiotem szczególnej uwagi, a nawet czułości pisarza stają się bowiem te elementy przeszłości, które - w jakimś sensie stały się ofiarami agresywnego kapitalizmu i gwałtownych procesów modernizacyjnych. Nowaczewski słusznie podkreśla, że pisarz „jak

\footnotetext{
16 Pisze o tym m.in. Artur Nowaczewski, dz.cyt., s. 109.

17 Dariusz Nowacki w recenzji Nekropolis 2 wspomina m.in: „Nowakowski wypowiada swoją mantrę «kiedyś było lepiej», ale nie problematyzuje jej treści, nie chce się dowiedzieć, dlaczego ją wypowiada. Przecież nie wszystko da się wytłumaczyć upływającym czasem; rytuały nostalgii niczego nie wyjaśnią, emocje są ślepe i bezrozumne”. Dariusz Nowacki, Nekropolis 2, „Gazeta Wyborcza”, 30.01.2008. Źródło internetowe: http://wyborcza.pl/1,75475,4884515.html, dostęp: 15.12.2015.
} 
wytrwały badacz rejestruje przemiany zachodzące w nowej epoce"18. Chciałoby się też powiedzieć, że niczym archiwista z niemałym trudem rejestruje ostatnie przejawy tego, co odchodzi w zapomnienie: opisuje przedmioty, domy, krajobrazy, a także zawody, a więc i typy ludzkie, które proces rozwoju cywilizacji zmiótł z miejskiej scenerii niczym uwiędłe liście.

\section{Archeologia miasta}

Informacje o tym, że narrator wszystkich części Powidoków i obu tomów Nekropolis będzie próbował wcielić się w rolę podobną do funkcji archiwisty, odnajdujemy już w samych tytułach zbiorów. Powidokami zdaje się rządzić zasada fotoplastykonu: kompozycja wszystkich trzech książek przypomina zbiór fotografii, przesuwających się przed odbiorcą. Wiele spośród nich to właśnie literackie „fotografie” takich postaci, które symbolizują pewien typ socjologiczny, a zatem pewien styl życia, należący do minionej epoki. Odnajdziemy tu sugestywne indywidualne i zbiorowe - portrety ${ }^{19}$ przedstawicieli przeróżnych rzemiosł i zawodów - wypieranych z rynku przez rozmaite formy produkcji masowej. Są to między innymi konterfekty producentów i sprzedawców balonów (P1, s. 57). Dowiemy się, że „wózkarze to była twarda kasta" (P1, s. 88). Zapoznamy się z panem Stefanem, ostatnim gołębiarzem z Powązek, bo - jak przekonuje autor - jeszcze nie tak dawno „p r z e d m i e ś c i a - a i śródmieście - pełne były gołębników” (P1, s. 100). Przeczytamy o masarniach we Włochach „prowadzonych przez rodziny" (P2, s. 32), a także o niezwykłym statusie społecznym peerelowskiego magazyniera ( $\mathrm{P}_{2}$, s. 142); o dorożkarzach i miejskich stajniach $\left(\mathrm{P}_{2}, \mathrm{~s} .35\right)$ oraz wielu innych przedstawicielach świata niepoddanego ani współczesnemu umasowieniu, ani dominującym wcześniej formom gospodarki socjalistycznej.

Wiele ze swych fotografii pisarz wykonuje w taki sposób, jakby chciał nie tylko utrwalić postacie ludzi, ale także wskazać na ich wartość, podkreślić swój szacunek wobec nich. Nie ma już bufetowych,

\footnotetext{
18 Artur Nowaczewski, dz.cyt., s. 109.

19 Por. Maciej Dęboróg-Bylczyński, Portrety, „Śląsk” 2007, nr 2, s. 77.
} 
bo i nie ma bufetów. W prozie Nowakowskiego przedstawicielki tego zawodu mają jednak swój wspaniały pomnik. Wszak pisarz wyraźnie podkreśla:

Należy się im hołd. Tym cierpliwym, wyrozumiałym szafarkom wody ognistej i nie tylko. Były bowiem powiernicami, spowiedniczkami [P2, s. 95].

Z pejzażu nowoczesnego miasta znika uliczny handel warzywami i owocami. Może właśnie dlatego autor zaznacza:

Należy się hołd tym babom [...] posiniałym od mrozu, które zgrabiałymi palcami odważały renety [...]. Staczały potyczki z władzą [P2, s. 29].

W tomach Nekropolis poetyka fotoplastykonu zdaje się jednak ustępować strategii archeologa. Małgorzata Czermińska sugeruje w swym artykule, że miejsce autobiograficzne to przestrzeń stała oswojona, oglądana z perspektywy kogoś dobrze zakorzenionego, kogoś, kto uczynił ją częścią swojej własnej biografii, swego prywatnego wszechświata ${ }^{20}$. Późna twórczość Marka Nowakowskiego każe jednak zwrócić uwagę na fakt swoistego „ruchu” wciąż zmieniającej się przestrzeni. Miasta, w których rodzimy się i w które wrastamy, podlegają nieustannym przemianom. A jeśli tak, to podmiotowi może towarzyszyć zarówno doświadczenie zakorzeniania się, uwłaszczania się w nowej przestrzeni, jak i narastające poczucie postępującej obcości przestrzeni dawniej uważanej za własną. Tak właśnie dzieje się w ostatnich książkach Nowakowskiego. Doświadczenie przemiany czy nawet zniknięcia miejsc, uważanych kiedyś za niewzruszone, generuje w nich rozmaite strategie narracyjne przypominające czynności archeologa. Ich źródłem staje się odnaleziony ślad - jakiś okruch wskazujący na przeszłość. Patrząc na współczesne miasto, narrator Nowakowskiego jest w stanie dostrzec skryte poza nowymi gmachami cienie niegdysiejszej architektury miasta:

20 Małgorzata Czermińska, dz.cyt., zwłaszcza s. 188-193. 
Plac przed Teatrem Wielkim. Jeszcze nie było atrapy ratusza. Ani gmachów bankowych [N1, s. 15].

Podobnych fraz jest w Nekropolis więcej. Bodźcem do wspomnień bywa w autobiograficznych zapiskach pisarza sama tylko nazwa ulicy, miejsce, w którym stoi teraz inny dom niż dawniej, inna niż kiedyś restauracja. Czytamy na przykład:

Świtezianka nie istnieje. W tym samym miejscu powstał nowy lokal o włoskiej nazwie. Nie zachodzę tam [N1, s. 159].

Choć w cytowanym fragmencie dominuje ton niechęci wobec nowego lokalu o niepolskiej nazwie, na kolejnych stronach Nekropolis ożywają postacie wypełniające dawną Świteziankę, autor wskrzesza atmosferę restauracji, jej osobliwy koloryt, a przede wszystkim jej miejsce w socjosferze i znaczenie dla jej bywalców. Tak jak archeologowi, nie chodzi mu tylko o przypomnienie tego, co kiedyś było w tym, a nie innym miejscu, lecz o ewokację dawnego stylu życia, dawnego społeczeństwa i jego obyczajów oraz mentalności, jednym słowem: minionego klimatu egzystencjalnego. Zdarza się, że architektura kieruje myśl pisarza w stronę języka, w stronę dawnej gwary warszawskiej.

Kino Atlantic, hotel Terminus trwały niby pomniki dawnego miasta. Mowa na ulicy dłużej się uchowała niż gdzie indziej [P1, s. 219].

Nucie żalu, jaka pojawia się we wspomnieniach pisarza, towarzyszy niekiedy gorzkie przeświadczenie, że dzieła zniszczenia śladów dawnej Warszawy nie zdołały dokonać ciężkie okowy totalitarnego reżimu, lecz dopełniły go współczesne procesy modernizacyjne. Takie myśli podsuwa pisarzowi współczesny widok ulicy Chmielnej:

Chmielna przez cały socjalizm zachowała się jako relikt przeszłości. Pozostała enklawą małych sklepików, warsztatów, zegarmistrzów, grawerów. Przetrwały nawet niektóre przedwojenne firmy [P2, s. 219].

Szczególnym terenem podobnych archeologicznych eksploracji stają się Włochy, które były miejscem zamieszkania pisarza i jego rodziny w czasach młodości. Poetyka „nekropolii” właśnie we 
„włoskich” wspomnieniach zdaje się u Nowakowskiego osiągać swą najbardziej krystaliczną postać. Sytuacja wędrówki, spaceru jest tu bowiem rozgrywana na stosunkowo niewielkiej przestrzeni. Swój palimpsestowy charakter ujawniają tu zatem poszczególne posesje i pojedyncze domy. Narrator pamięta historię każdego z nich, czyli dzieje jego mieszkańców. Z radością odkrywa, że nie wszystkie budynki zniknęły. Notuje na przykład:

Dom Maslichów uchował się i jeszcze do niedawna mieściło się tam przedszkole [P1, s. 22].

O archeologicznym wymiarze późnej prozy Nowakowskiego możemy jednak mówić w innym jeszcze sensie. Wymiar ten chciałoby się nazwać wewnątrztekstowym, bo rzeczywiście dotyczy on wyłącznie świata przedstawionego w prozie pisarza. Czytelnik jego fikcjonalnych utworów nie bez dreszczyku emocji zauważy, że w prozie autobiograficznej pisarz dokonuje swoistej archeologii konstruowanych przez siebie postaci, ujawniając, że ich pierwowzory (podobnie jak pierwowzory scenografii i zdarzeń) bynajmniej nie są fikcjonalne. Odsłania tym samym obszar niezmiernie ciekawy, wymagający intensywnych badań. Miejmy nadzieję, że doczekają się one realizacji.

\section{Summary \\ Place and Memory in Marek Nowakowski's late works. Prolegomena}

Since 1990s Marek Nowakowski has systematically expanded the sphere of memoir-writing prose, which he built himself. In this prose it is spatial elements that first and foremost evoke images of the past, and a flâneur often becomes narrator. Gazing at architectural and urbanistic changes, he gives himself to memoirs. Various gastronomic establishments, understood as places of freedom, are particularly important goals of his journey to the past. Nowakowski also eagerly mentions specific individuals as well as types of their professions, which allowed for independence from the totalitarian rule of the Polish People's Republic. 
Wojciech Kudyba (Uniwersytet Kardynała Stefana Wyszyńskiego w Warszawie) - prof. nadzw. dr hab. w Katedrze Literatury Współczesnej UKSW; autor książki «Aby mowę chrześcijańska odtworzyć na nowo...». Norwida mówienie o Bogu (Lublin 200o) oraz kilku monografii o poezji współczesnej: Rana, która przyzywa Boga. O twórczości poetyckiej Janusza St. Pasierba (Lublin 2007), Wiersze wobec Innego (Sopot 2012), Generacja źle obecna (Sopot 2014), a także artykułów naukowych publikowanych m.in. w: „Ethosie”, „Pamiętniku Literackim”, „Rocznikach Humanistycznych KUL”, „Ruchu Literackim”, „Studiach Norwidianach”, „Tekstach Drugich”; członek Komisji Języka Religijnego Polskiej Akademii Nauk i Towarzystwa Naukowego KUL. 